УДК $78.03+782 / 784.9$

DOI https://doi.org/10.31723/2524-0447-2020-30-2-27

Ірина Володимирівна Берлізова

ORCID: 0000-0001-7479-0509

заслужена артистка України,

доцент кафедри сольного співу

Одеської національної музичної академії імені А. В. Нежданової irinameizu22@gmail.com

\title{
ПРИНЦИПИ «ЗВІЛЬНЕННЯ ГОЛОСУ» К. ЛИНКЛЕЙТЕР У КЛАСІ АКАДЕМІЧНОГО ВОКАЛУ: МУЗИЧНО-ІСТОРИЧНИЙ АСПЕКТ
}

Метою статті є розкриття методичних принципів $i$ педагогічних настанов видатного американського педагога Крістін Линклейтер (1936-2020) та освоєння принципів «звільнення голосу» як важливої складової частини виховання сучасного вокаліста-виконавия у класі академічного вокалу. Методологія роботи грунтується на музично-виконавському, музикознавчому аналітичному, історичному підходах із виділенням провідних методичних питань постановки голосу та вокальної педагогіки загалом. Наукова новизна статті пов'язана з виявленням і розглядом актуальних питань постановки голосу в процесі освоєння художньо-виконавської майстерності та підготовки вокалістів на матеріалі методичних розробок видатних вокальних педагогів минулого та сучасності. Простежені та систематизовані умови, що є основою для формування ефективної виконавської діяльності вокалістів під час навчання у музичних навчальних закладах.

Висновки. Формування творчої індивідуальності співака й освоєння різних рівнів і граней професійної майстерності виконавия-вокаліста пов'язані, з одного боку, з музично-технологічними та психофізіологічними параметрами володіння голосовим апаратом, з іншого - з необхідністю створення переконливого художнього образу, у т. ч. за допомогою природньої акторської обдарованості й отриманих під час навчання навичок. Голос людини як складне за своїми параметрами й унікальне за художніми властивостями музично-виконавське й акустичне явище має онтологічну природу. Якщо явище людського голосу розглядати 3 позиції фізіології, то він є поєднанням і відтворенням голосовим апаратом людини різноманітних звуків; при розгляді голосу як психологічного феномену він стає способом самовираження та будування діалогічної взаємодії з навколишнім світом і соціокультурним середовищем. Вокальне мистецтво загалом і людський голос зокрема через вокальну

(C) Берлізова I. В., 2020 
інтонацію транслюють емоційні стани, особистісні почуття, настрій людини та ї̈ ставлення до тієї чи іншої ситуації.

Ключові слова: постановка голосу, Крістін Линклейтер, академічний вокал, мистецтво співу, вокальне інтонування.

Berlizova Iryna Volodymyrivna, Honored Artist of Ukraine, Associate Professor at the Department Solo Singing of the Odessa National A. V. Nezhdanova Academy of Music

Principles of "voice release" $K$. Linclauter in the academic vocal class: music-historical aspect

The aim of the article is to reveal the methodological principles and pedagogical guidelines of the outstanding American teacher Kristin Linklater (1936-2020) and to master the principles of "Voice Way" as an important component in the education of a modern vocalist in the academic vocal class. The methodology of work is based on musical-performing, musicological analytical, historical approaches with the selection of both leading methodological issues of voice production and vocal pedagogy in general. The scientific novelty of the article is related to the identification and consideration of topical issues of voice production in the process of mastering artistic and performing skills and training of vocalists on the material of methodological developments of outstanding vocal teachers of the past and present. Traced and systematized conditions that are the basis for the formation of effective performance of vocalists while studying in music schools.

Conclusions. The formation of the singer's creative personality and the development of different levels and facets of the vocalist's professional skills are associated, on the one hand, with musical-technological and psychophysiological parameters of voice, on the other - with the need to create a convincing artistic image, including natural acting giftedness and skills acquired during training. The human voice, as a musical-performing and acoustic phenomenon complex in its parameters and unique in its artistic properties, is based on its ontological nature. If the phenomenon of the human voice is considered from the point of view of physiology, then it is a combination and reproduction of the human vocal apparatus of various sounds; when considering the voice as a psychological phenomenon, it becomes a way of self-expression and building dialogical interaction with the world around and the socio-cultural environment around a person. Vocal art in general, and the human voice in particular, through vocal intonation translates emotional states, personal feelings, human mood and attitude to a situation, that means, it can express the spiritual essence of both his hero and himself.

Key words: voice staging, Kristin Linklater, academic vocals, art of singing, vocal intonation.

Берлизова Ирина Владимировна, заслуженная артистка Украины, доцент кафедры сольного пения Одесской национальной музыкальной академии имени А. В. Неждановой

Принципы «освобожддения голоса» $K$. Линклэйтер в классе академического вокала: музыкально-исторический аспект 
Целью статьи является раскрытие методических принципов и педагогических установок выдающегося американского педагога Кристин Линклэйтер (1936-2020) и освоение принципов «освобождения голоса» как важной составляющей в воспитании современного вокалиста-исполнителя в классе академического вокала.

Методология работы основывается на музыкально-исполнительском, музыковедческом аналитическом, историческом подходах с выделением ведущих методических вопросов постановки голоса. Научная новизна статьи связана с выявлением и рассмотрением актуальных вопросов постановки голоса в процессе освоения художественно-исполнительского мастерства и подготовки вокалистов на материале методических разработок видающихся вокальных педагогов прошлого и современности. Систематизированы условия, которые являются основой для формирования эффективной исполнительской деятельности вокалистов во время обучения в музыкальных учебных заведениях.

Выводы. Формирование творческой индивидуальности певиа и освоение различных уровней и граней профессионального мастерства исполнителя-вокалиста связаны, с одной стороны, с музыкально-технологическими и психофизиологическими параметрами владения голосовым аппаратом, с другой - с необходимостью создания убедительного художественного образа, в т. ч. с помощью природной актерской одаренности и полученных во время обучения навыков. Голос человека как сложное по своим параметрам и уникальное по художественным свойствам музыкально-исполнительское и акустическое явление имеет онтологическую природу. Если явление человеческого голоса рассматривать с точки зрения физиологии, то он представляет собой сочетание и воспроизведение голосовым аппаратом человека звуков; при рассмотрении голоса как психологического феномена он становится способом самовыражения и построения диалогического взаимодействия с окружающим миром и окружающей человека социокультурной средой. Вокальное искусство в целом и человеческий голос в частности через вокальную интонацию транслируют эмоциональные состояния, личностные чувства, настроение человека и его отношение к той или иной ситуации.

Ключевые слова: постановка голоса, Кристин Линклэйтер, академический вокал, искусство пения, вокальное интонирование.

Актуальність теми дослідження. Вокальне мистецтво у всіх його жанрово-стильових різновидах є одним із найдавніших і найважливіших видів мистецтва, досліджуючи який, можна простежити генезу та всі етапи подальшого історичного розвитку світової музичної культури загалом. Голос стає головним інструментом, за допомогою якого музичний твір отримує процесуальне, художньо-емоційне, інтерпретаційне вираження та може бути презентований слухацькій аудито- 
piï. Професійна діяльність вокаліста та його результативність як концертуючого виконавця й посередника між композитором, його твором і слухачем починається та багато в чому залежить від процесу постановки голосу, який має надзвичайне значення для формування виконавської майстерності, розкриття тембрових якостей і демонстрування обдарованості вокаліста як інтерпретатора музичного твору. Тому проблемою вивчення всіх методичних і технологічних аспектів процесу постановки голосу й оволодіння психоемоційними, художньо-виразними властивостями опікувалися дослідники можливостей людського голосу з часів Аристотеля та Демосфена і дотепер (праці К. Линклейтер, С. Фучіто, Б. Бейєра, О. Пекерської, А. Менабені, Н. Ангуладзе, та ін.). Кожен 3 означених авторів виділяв ті чи інші ключові характеристики голосу, пріоритетні для вокального виконавства загалом і для постановки голосу зокрема.

Протягом останніх десятиліть у світовій вокально-педагогічній практиці можна спостерігати суттєві модифікації вокально-педагогічної методики, що пояснюється значними змінами у тих завданнях, які сьогодні $є$ актуальними для сучасних виконавців-вокалістів і зумовлені розвитком музично-театрального мистецтва та сучасної концертної практики. Стало очевидним, що тільки багатошарове та комплексне оволодіння технікою співу, різними виконавськими способами відповідно до тієї історичної епохи, до якої належить виконуваний твір, може дозволити говорити про повноцінне виховання сучасного виконавця-вокаліста. У багатьох випадках специфіка інтонування вокальної музики та пов'язана 3 нею постановка голосу полягає в обов'язковій опорі на попередні уявлення слухового образу з метою озвучення відповідної інтонації. Академічна освіта формує голос співака, спираючись на музично-мовні та музично-стилістичні принципи композиторської творчості XVIII-XIX ст., тобто, за рідкісним винятком, фактично лишаючи за межами академічної освіти твори доби бароко або композиторів XX-XXI ст. Підходи, запропоновані К. Линклейтер, дозволяють зняти напруження цієї проблемної зони у сучасній вокальній методиці.

Метою статті $є$ розкриття методичних принципів і педагогічних настанов видатного американського педагога Крістін Линклейтер (1936-2020) та освоєння принципів «звільнення 
голосу» як важливої складової частини виховання сучасного вокаліста-виконавця у класі академічного вокалу.

Методологія роботи грунтується на музично-виконавському, музикознавчому аналітичному, історичному підходах із виділенням провідних методичних питань постановки голосу та вокальної педагогіки загалом.

Наукова новизна статті пов'язана 3 виявленням і розглядом актуальних питань постановки голосу у процесі освоєння художньо-виконавської майстерності та підготовки вокалістів на матеріалі методичних розробок видатних вокальних педагогів минулого та сучасності. Простежені та систематизовані умови, що є основою формування ефективної виконавської діяльності вокалістів під час навчання у музичних навчальних закладах.

Виклад основного матеріалу. Людський голос у музично-історичному розвитку культури займає одне з найбільш значних місць. Як вказував Н. Ангуладзе: «Звук, голос, мова, спів, музика є невід'ємними частинами людського буття. Тому можна стверджувати: людський голос містить у собі історію людства» [2, с. 19]. Будучи неодмінним атрибутом людства протягом багатьох століть, голос невідривно супроводжує людину у всіх видах діяльності та стає способом заявити про себе й отримати можливість впливати на навколишній світ. Одним із перших факторів у формуванні професійних основ вокального мистецтва є виникнення оперного жанру в 1599 р. у Флоренції, коли у Палаццо Кореї з вистави «Дафна» Я. Пері розпочалася історія європейської опери. Поруч із виникненням явища опери одночасно відбулося закладення основ вокальної педагогіки, адже у зв'язку з підготовкою співаків до сценічного виступу виробляються принципи техніки дихання, формування вокального звуку та постанови голосу.

Як свідчать численні праці, присвячені розгляду музичного мистецтва у контексті історії культури певної доби, вже у 1600 р. у святкових заходах із нагоди одруження Марії Медичі з Генріхом IV, королем Франції була виконана опера «Евридіка» Дж. Каччіні, де всі слухачі мали можливість насолоджуватися голосами дочок композитора - Франчески та Сеттимо Каччіні. Відомо, що більшість композиторів початку XVII ст. мали відношення до виховання виконавців-вокалістів і підготовки їх для участі в оперній виставі, що дозволяло детально працювати над втіленням образів героїв оперного твору у 
сценічній дії [5]. XVII століття стає тим історичним періодом, коли починається формування національних вокальних шкіл у країнах Західної Європи, кожна з яких характеризується неповторним стилем виконання, характерною манерою ведення звуку й унікальними якостями співочого звуку. Тобто саме у цей період з'являються універсальні історичні особистості, котрі поєднують в одній особі композитора, педагога та співака, одночасно виникають національні композиторські школи, які висувають перед цими творчими особистостями певні художньо-виконавські вимоги. У національній вокальній манері співу відображаються виконавські традиції, особливості мови, темпераменту, характеру, інтонаційні, ладові та ритмічні компоненти конкретної країни та регіону, їхня народна музика [5].

Таким чином, із самого початку свого існування професійне вокальне мистецтво спиралося на множинність підходів до формування культури вокального співу, а також на ті художньо-естетичні добутки, які були сформовані у надрах національних шкіл і їхніх практик навчання. Славетна італійська школа сольного співу bel canto, що склалася на початку XVII ст., на чільне місце ставила художні та технічні характеристики вокального співу та відрізнялася досконалістю володіння голосом. Центрами вокального навчання в Італії XVII-XVIII ст. були закриті навчальні заклади - консерваторії, в яких навчалися діти віком від 6-7 років, а строк навчання становив не менш ніж 10-12 років. Програми навчання у консерваторіях відрізнялися надзвичайною насиченістю та напруженістю, що ставало запорукою виховання освіченого музиканта, який володіє основами композиції, декількома музичними інструментами, засвоїв навички викладання вокалу, тобто того, хто має глибокі знання у професійній сфері та здатен справлятися з вокально-технічними труднощами. Отримати звання вчителя міг тальки співак, бо весь процес навчання будувався на емпіричній методиці, де власний співацький досвід і безпосередній показ під час навчання був обов'язковою умовою. Однак вимоги до особистості вчителя цим не обмежувалися - до його творчо-особистісних якостей мали входити знання основ i методів композиції, здатності до музикознавчої діяльності та загальна широка ерудиція. Яскравими прикладами вчителів-подібного рівня можна назвати видатних представників 
тогочасної музичної культури: К. Монтеверді, А. Страделла, Фр. Каваллі [3; 5].

Сучасне мистецтво вокального виконавства розширило свою художню впливовість і діапазон, увібравши в себе різноманіття видів і жанрів музичної діяльності. Серед театрально-сценічних жанрів треба назвати всі жанрові різновиди опери, оперету, музично-драматичні постанови, мюзикл, та ін.; серед концертних жанрів - камеро-вокальні твори, мініатюри, концертні твори для різних складів учасників. Треба зазначити, що кожен із названих жанрових різновидів вимагає особливих принципів роботи 3 вокальним матеріалом i способів вирішення художніх завдань, що провокує суттєве оновлення характерологічних виконавських прийомів, нових форм роботи зі звуком, а також збільшення уваги до акторської майстерності та сценічного руху.

У багатьох мистецтвознавчих роботах розповсюджена думка про те, що специфічною особливістю мистецтва загалом є образне відображення дійсності, тож специфічною особливістю кожного з видів мистецтва буде особливий спосіб, особлива форма образного відображення, тобто те, яким способом у цьому конкретному виді мистецтва досягається образне відображення дійсності, як вирішується проблема образу [1]. Для співака-вокаліста такою особливістю $є$ сам голос, а всі виконавсько-інтерпретаційні завдання будуть підпорядковані демонстрації вокальних якостей співака, а саме тембровій забарвленості голосу, його діапазону та здатності вільно користуватися музичними штрихами та динамічними відтінками, переконливість у створенні художнього образу. Водночас сучасний еталон академічного вокального виконавства передбачає, крім досконалого володіння технікою вокалу, виразні якості, неабиякі акторські обдарування, що дозволять створити довершений сценічний образ та ініціювати творчий діалог зі слухацькою аудиторією.

Відомий знавець, дослідник співочого голосу та фізіолог Р. Юссон визначає метод виховання співочого голосу як «сукупність систематизованих вказівок і порад, поступове засвоєння яких призводить до появи у будь-якої здорової людини певних співочих навичок або вокальної техніки, що забезпечує бажаний діапазон, силу і тембр голосу за нестомлюваності голосового апарату» [6, с. 178]. У сучасній вокальній педагогіці $€$ таке поняття, як м'язовий прийом, який 
складається з безпосереднього свідомого впливу на роботу окремих складових частин голосового апарату, що дозволяє корегувати якість вокальної інтонації.

Сучасні дослідники методичних аспектів навчання у класі академічного вокалу повністю погоджуються зі своїми славетними попередниками - вокальними педагогами минулого, щодо того, що вчити вокалу може тільки той, хто сам досконало володіє технікою співу. Нодар Ангуладзе стверджував, що використання конкретних м'язових прийомів у досягненні ідеалу звучання вимагає від педагога чіткого розуміння природи голосу учня й ретельного контролю над правильністю виконання вправ - «хто не володіє прийомом, не повинен і навчати його» [2, с. 7].

Серед багатьох методичних розробок навчання мистецтва співу увагу привертає методика «звільнення голосу», запропонована видатним американським педагогом вокалу й акторської майстерності Крістін Линклейтер. Слід зазначити, що формування та сучасні умови існування вокального мистецтва у США мають багато спільного з європейською традицією академічного співу, наприклад, тяжіння до інструменталізму співу, завдяки якому функційне призначення та художнє трактування голосу наближається до інструменту. Водночас система музичної вокальної освіти суттєво відрізняється від європейської, що робить досвід американських педагогів надзвичайно цікавим для музичних закладів Европи.

Дослідження К. Линклейтер «Звільнення голосу» стало справжнім бестселером і неодноразово виходило у крупних видавництвах США та Свропи, у т. ч. у перекладах багатьма європейськими мовами. Головне завдання, яке дослідниця ставила перед собою, - розробити систему, завдяки котрій можна буде звільнити голос від напруги, вплинути на його розвиток i поширити його можливості як найдосконалішого інструменту, хоча у методиці К. Линклейтер це швидше розуміється як звільнення природного голосу, ніж розвиток голосової техніки. Перші розділи авторка присвячує питанням формування голосу у безпосередньому контакті з емоційними імпульсами, тобто завдяки інтелектуальним зусиллям, де звучання голосу $€$ результатом фізичних процесів. Вказані фізичні процеси $є$ реакцією м'язів тіла, що мають бути вільними від напруги, на імпульси мозку, які ініціюються з боку мовленнєвого апарату. Природний стан голосового апарату найбільш помітно блоку- 
ється такими психофізіологічними перешкодами, як фізична напруга, інтелектуальні, душевні й емоційні затискачі. К. Линклейтер стверджує, що тільки у разі усунення вищеназваних факторів голос співака може передавати весь діапазон людських емоцій і все багатство думки, що є необхідною умовою для створення переконливого художнього образу [4].

К. Линклейтер вибудовує схему роботи голосу, стверджуючи, що порушення будь-яких іiі складників призведе до негативних наслідків та унеможливіть нормальну роботу голосу, його перебування у стані звільнення. Дія механізму голосового апарату починається з імпульсу у руховій частині кори головного мозку та бере участь у формуванні мови, що веде до низки дій дихальних м'язів і зниження тиску грудної клітини, завдяки чому «повітря відносно вільно проникає в легені» [4]. Після цього, «коли в легенях набереться повітря в достатній кількості, м'язи живота та грудної клітини виштовхують повітря назад через ділянку звукового каналу горла, рота й носа, а голосові складки частково закривають глотку, перешкоджаючи потоку повітря, його виходу» [4]. Наступною фазою дії механізму голосового апарату стає вібрація пластичних голосових складок і розділення єдиного потоку повітря, який «поривами проходить через звуковий канал» і приводить його у резонаторні порожнини «рота і носа, формуючи звук у звуковому каналі» [4]. Авторка вказує, що саме «форма, обсяг, ступінь відкритості резонатора визначає якість звуку обертонів, тоді як висота звуку залежить від темпу, в якому вібрують голосові складки» [4].

К. Линклейтер детально розглядає дію механізму голосового апарату, але іiі турбує не роз'яснення всіх етапів цього психофізіологічного процесу, а точне розуміння його структури з метою простеження всіх можливих негативних сценаріїв у процесі формування вокального звуку та подолання цієї ситуації за допомогою запропонованих нею вправ. Наступним етапом у дослідженні К. Линклейтер стає докладне вивчення усіх негативних можливостей і з'ясування причин, чому голос не працює. Окремим розділом роботи стає рух у бік «звільнення голосу», задля чого авторка пропонує низку вправ і методичних вказівок стосовно положення тіла, правил дихання, звукоутворення, контролю за звуковим каналом, артикуляції та відчуття центру. Нерідко дуже докладні рекомендації автор супроводжує графічними зображеннями. 
Висновки. Формування творчої індивідуальності співака й освоєння різних рівнів і граней професійної майстерності виконавця-вокаліста пов'язані, з одного боку, з музично-технологічними та психофізіологічними параметрами володіння голосовим апаратом, з іншого - необхідністю створення переконливого художнього образу, у т. ч. за допомогою акторської обдарованості й отриманих під час навчання навиків.

Голос людини - складне за своїми параметрами й унікальне за художніми властивостями музично-виконавське й акустичне явище. Якщо явище людського голосу розглядати з позиції фізіології, то він є поєднанням і відтворенням голосовим апаратом людини різноманітних звуків; при розгляді голосу як психологічного феномену він стає способом самовираження та будування діалогічної взаємодії з навколишнім світом і соціокультурним середовищем. Вокальне мистецтво загалом і людський голос зокрема через вокальну інтонацію транслюють емоційні стани, особистісні почуття, настрій людини та іiї ставлення до тієї чи іншої ситуації.

Актуальні сьогодні вокальні методики, у т. ч. К. Линклейтер, стверджують, що голос може відповідати всім професійним вимогам і бути повноцінно сформований лише за координованої роботи всіх частин, які складають голосовий апарат, і повного розуміння функціонування всієї системи роботи голосу. Результативність професійного виховання виконавця-вокаліста залежить рівною мірою як від обдарованості учня та наполегливості його під час навчання, так і від талановитості педагога, його зосередженості на співтворчості з учнем.

\section{СПИСОК ЛІТЕРАТУРИ}

1. Авдеев А. Происхождение театра. Элементы театра в первобытнообщинном строе. Ленинград - Москва : Искусство, 1959. $268 \mathrm{c}$.

2. Ангуладзе Н. Ноmo cantor: Очерки вокального искусства. Москва : Аграф, 2003. 240 с.

3. Дмитриев Л. Основы вокальной методики. Москва : Музыка, 2007. $368 \mathrm{c}$.

4. Линклэйтер К. Освобождение голоса. Москва : ГИТИС, 1993. $176 \mathrm{c}$.

5. Шушкова О. Раннеклассическая музыка: Эстетика, стилевые особенности, музыкальная форма : дисс. ... докт. искусствоведения : 17.00.02. Новосибирск, 2002. 323 с.

6. Юссон Р. Певческий голос. Москва : Музыка, 1974. 264 с. 


\section{REFERENCES}

1. Avdeev, A. (1959) The origin of the theater. Elements of theater in the primitive communal system. Leningrad - Moscow: Art. [in Russian].

2. Anguladze, N. (2003) Homo cantor: Essays on vocal art. Moscow: Agraf. [in Russian].

3. Dmitriev, L. (2007) Fundamentals of vocal techniques. Moscow: Muzyka. [in Russian].

4. Linklauter, K. (1993) Freeing the Voice. Moscow: GITIS. [in Russian].

5. Shushkova, O. (2002) Early classical music: Aesthetics, stylistic features, musical form: dissertation ... doctor of arts: 17.00.02. Novosibirsk. [in Russian].

6. Yusson, R. (1974) Singing voice. Moscow: Muzyka, 1974. [in Russian].

УДК 78.071.2+78.071.4

DOI https://doi.org/10.31723/2524-0447-2020-30-2-28

\section{Олег Павлович Бадалов}

ORCID: 0000-0002-2706-1458

кандидат мистецтвознавства, старший викладач кафедри теорії, історії і практики культури

Чернігівської філії

Національної академії керівних кадрів культури і мистецтв oleg.p.badalov@gmail.com

\section{МУЗИЧНО-ПЕДАГОГІЧНА ДІЯЛЬНІСТЬ І. КЛІМОВОЇ ЯК СКЛАДНИК ФОРМУВАННЯ КУЛЬТУРНОГО ПРОСТОРУ ЧЕРНІГІВЩИНИ}

Мета публікації - вивчення мистецької діяльності піаністки, педагога, фундатора фортепіанного відділу Чернігівського музичного училища ім. Л. Ревуцького Ірини Петрівни Клімової (1927-2007), з'ясування ї̈ внеску у формування культурного простору Чернігівщини. Автор досліджує життетворчість I. Клімової у контексті ї̈ культурно-просвітницької діяльності у регіоні як піаністки-виконавиці та викладачки за класом фортепіано. Методологія статті грунтується на істори-

(С Бадалов О. П., 2020 